\title{
Physiological tolerances across latitudes: thermal sensitivity of larval marine snails (Nucella spp.)
}

\author{
Mackenzie L. Zippay · Gretchen E. Hofmann
}

Received: 1 February 2009 / Accepted: 18 November 2009 / Published online: 4 December 2009

(C) The Author(s) 2009. This article is published with open access at Springerlink.com

\begin{abstract}
A critical step in understanding how temperature will affect biodiversity in coastal ecosystems is to gain insight into how the tolerances, and ultimately survival, of early life history stages will influence the distribution and abundance of adults. We assessed the thermal tolerance of encapsulated veliger-stage larvae of a common dogwhelk, Nucella ostrina, that occur in the rocky intertidal zone on the west coast of North America. Results showed that veligers collected from northern latitudes in Washington State were less tolerant of heat stress than those from central sites in California. For all sites, we found there to be a subtle difference between the temperatures at which veligers first began to die compared to when veligers reached $100 \%$ mortality. On a biogeographic scale, the $\mathrm{LT}_{50}$ temperatures, a measure of larval sensitivity, for $N$. ostrina veligers displayed a strong latitudinal trend. These findings provide a conservative measurement of the upper thermal limits of encapsulated veligers while illustrating how these early life history stages could be physiologically compromised under future climate warming scenarios.
\end{abstract}

Communicated by S. A. Poulet.

M. L. Zippay · G. E. Hofmann

Department of Ecology, Evolution, and Marine Biology,

University of California, Santa Barbara, CA 93106-9620, USA

G. E. Hofmann

Marine Science Institute, University of California,

Santa Barbara, CA 93106-9620, USA

Present Address:

M. L. Zippay ( $\square)$

Medical University of South Carolina,

Hollings Marine Laboratory, 331 Fort Johnson Road,

Charleston, SC 29412, USA

e-mail: zippay@musc.edu

\section{Introduction}

Although larval forms have been traditionally recognized as a vulnerable stage in the life history of marine organisms (Wilson 1973; Jackson and Strathmann 1981, but see Hamdoun and Epel 2007), few studies have explored the tolerances of embryos or larvae in broad ecological terms (Fernández et al. 2007). Existing research has focused on thermal tolerance differences among developmental stages (e.g., Pedersen and Tande 1992; Sewell and Young 1999; Lu et al. 2004) and temperature effects on the pelagic larval duration (PLD) and their ecological consequences (O'Connor et al. 2007). The importance of understanding the vulnerabilities of larval life history stages in marine invertebrates lends recognition to the emerging field of ecological development (see Sultan 2007). In this study, we tested the thermal tolerance of veligers of the marine dogwhelk, Nucella ostrina, a common, broadly distributed inhabitant of the rocky intertidal of the Northeastern Pacific. Additionally, we tested whether there were any differences in physiological tolerance that could be linked to biogeographic distribution.

The dogwhelks of the Northeastern Pacific coast are an ideal system with which to address the role of physiological capacities, such as thermal tolerance, in setting species range boundaries in the rocky intertidal zone. These intertidal snails lack a planktonic larval stage and develop in egg capsules to juveniles that hatch out and 'crawl away' (Morris et al. 1980). Females lay yellow, stalk-like egg capsules that contain numerous developing embryos (Spight and Emlen 1976), fixed on benthic substrates (Thorson 1950). Thus, these egg capsules are routinely exposed to elevated air temperatures during emersion and cooler seawater temperatures during immersion, making them an ideal biological indicator for environmental thermal stress. Nucella 
ostrina are commonly found in the mid-high intertidal zone within and among mussel beds and barnacles. In coastal sites along the US Pacific Northwest, female $N$. ostrina can produce egg capsules year-round, although they are more abundant during the winter and spring when food supply is more favorable (Seavy 1977; Moran and Emlet 2001). During development to trochophore and later to veliger stages, embryos feed on nurse eggs (unfertilized eggs or non-developing embryos) within the egg capsule (LeBoeuf 1971). After 2.5-4 months of encapsulated development, individuals hatch as metamorphosed juvenile snails (Costello and Henley 1971; Morris et al. 1980). Unlike juvenile and adult stages of Nucella, the sessile egg capsules are not able to actively avoid abiotic stressors (e.g., desiccation, temperature) by moving to less stressful microhabitats. As a result, developing larvae may represent a significant stage of vulnerability for this marine gastropod. Thus, understanding the physiological responses underlying the development of encapsulated embryos is a key step in defining environmental parameters that can contribute to setting a species range boundaries.

Previous studies have shown that survivorship of early life history stages can be significantly impacted by environmental factors and ultimately influence adult populations (barnacles, Connell 1985; polychaetes, Qian and Chia 1994; oysters, Roegner and Mann 1995; snails, Gosselin and Qian 1997; Moran and Emlet 2001). Additionally, a few studies have looked at the effects of temperature on encapsulated development (Boon-Niermeijer and Van de Scheur 1984; Przeslawski 2005; Fernández et al. 2007); however, to our knowledge, none have addressed survivorship during encapsulated development in Nucella. For later stages, mortality data on $N$. lamellosa juveniles estimate that 90-99\% die within the first year (Spight 1976) and only $1-2 \%$ of $N$. lapillus survive the first few months of life (Feare 1970). Other investigators have addressed potential biotic and abiotic sources of mortality (e.g., salinityPechenik 1983; desiccation-Gosselin and Chia 1995a; Rawlings 1999; sun exposure-Moran and Emlet 2001; predation-Spight 1976; Gosselin and Rehak 2007; wave exposure-Etter 1996; Gosselin and Rehak 2007; ultraviolet radiation-Rawlings 1996) in juvenile and encapsulated individuals. However, temperature, in particular, has not been well studied with respect to earlier stages of development. In regard to temperature tolerances of $N$. ostrina, very little is known about how thermal stress affects embryonic survivorship. Gosselin and Chia (1995b) found that N. ostrina (formerly N. emarginata, Marko 1998) hatchlings around Barkley Sound (Vancouver Island, Canada) were tolerant of temperatures as high as $26^{\circ} \mathrm{C}$; all hatchlings survived $8 \mathrm{~h}$ of exposure at 22 and $26^{\circ} \mathrm{C}$. Mortality among hatchlings did occur at $30^{\circ} \mathrm{C}$, whereas adults survived all temperature treatments. This study exemplifies the dichotomy that can exist between the impacts of temperature on juvenile and adult marine invertebrates.

To further explore the relationship of thermal tolerance and early life history stages, we characterized the temperature tolerance of encapsulated veligers of $N$. ostrina. This is the first study to measure the temperature tolerance of encapsulated Nucella veligers. In addition, given that $N$. ostrina has an expansive range distribution, from Yakutat, Alaska to Pt. Conception, CA (Vermeij et al. 1990; Collins et al. 1996), we tested the thermal tolerance of veligers collected from multiple sites within the species' biogeographic range in order to assess the relationship between latitudinal distribution and thermal tolerance. By identifying the upper thermal limits for these embryos, we hoped to contribute to our understanding of how the physiological tolerances of larval stages maps onto the distribution of the adult population.

\section{Materials and methods}

\section{Nucella collections}

During the breeding season, $N$. ostrina egg capsules were collected from seven mid- to high-intertidal sites between the months of May and July 2006 along the west coast of the United States across $\sim 13^{\circ}$ of latitude from Washington State to Central California. The collection locations are as follows: Cattle Point, San Juan Island, WA (CP); Boiler Bay, OR (BB); Strawberry Hill, OR (SH); Coos Bay, OR (CB); Humboldt, CA (HUM); Bodega Cove, CA (BML); Cambria, CA (RM) (see Table 1). At one collection site (Rancho Marino Reserve in Cambria, CA), $N$. ostrina overlaps in distribution with $N$. emarginata near Point Conception (Marko 1998). However, for this study, since genotyping was not conducted on the veligers, egg capsules collected from this site were called $N$. ostrina resembling the 'northern form' described by Palmer (1990) and later classified as N. ostrina by Marko (1998). At all sites, 15-30 egg capsules were haphazardly collected from 10-25 clutches by scraping egg capsules off the substrate and placing them in a mesh holding container. After collection, all egg capsules were immediately transported back to a marine facility near the site. Upon arrival, the egg capsules were placed in a flowthrough seawater tank containing seawater adjusted to the temperature of the location where the capsules were collected $\left(10-19^{\circ} \mathrm{C}\right)$. On average, experiments were run about 1-3 h after collection, and no collection of egg capsules was held for more than $12 \mathrm{~h}$ before experimentation began. 
Table 1 Collecting sites for Nucella ostrina

\begin{tabular}{|c|c|c|}
\hline Site of collection & Species collected & Coordinates \\
\hline $\begin{array}{l}\text { Cattle Point, WA } \\
\text { (CP) }\end{array}$ & Nucella ostrina & $\begin{array}{l}\text { N } 48^{\circ} 27.001^{\prime} \\
\text { W } 122^{\circ} 57.803^{\prime}\end{array}$ \\
\hline $\begin{array}{l}\text { Boiler Bay, OR } \\
\text { (BB) }\end{array}$ & Nucella ostrina & $\begin{array}{l}\mathrm{N} 44^{\circ} 50.001^{\prime} \\
\mathrm{W} 124^{\circ} 03.846^{\prime}\end{array}$ \\
\hline $\begin{array}{l}\text { Strawberry Hill, OR } \\
(\mathrm{SH})\end{array}$ & Nucella ostrina & $\begin{array}{l}\mathrm{N} 44^{\circ} 14.995 \\
\mathrm{~W} 124^{\circ} 06.808\end{array}$ \\
\hline $\begin{array}{l}\text { Coos Bay, OR } \\
\text { (CB) }\end{array}$ & Nucella ostrina & $\begin{array}{l}\text { N } 43^{\circ} 20.968^{\prime} \\
\text { W } 124^{\circ} 19.808^{\prime}\end{array}$ \\
\hline $\begin{array}{l}\text { Humboldt, CA } \\
\text { (HUM) }\end{array}$ & Nucella ostrina & $\begin{array}{l}\mathrm{N} 41^{\circ} 03.432^{\prime} \\
\mathrm{W} 124^{\circ} 08.957^{\prime}\end{array}$ \\
\hline $\begin{array}{l}\text { Bodega Marine Reserve } \\
\text { Bodega Cove, CA (BML) }\end{array}$ & Nucella ostrina & $\begin{array}{l}\text { N } 38^{\circ} 18.250^{\prime} \\
\text { W } 123^{\circ} 03.540^{\prime}\end{array}$ \\
\hline $\begin{array}{l}\text { Rancho Marino Reserve } \\
\text { Cambria, CA (RM) }\end{array}$ & Nucella ostrina ${ }^{\mathrm{a}}$ & $\begin{array}{l}\mathrm{N} 35^{\circ} 33.290^{\prime} \\
\mathrm{W} 121^{\circ} 10.580^{\prime}\end{array}$ \\
\hline
\end{tabular}

${ }^{a}$ Records may include $N$. emarginata in the southern part of the range of Nucella spp.

\section{Thermal tolerance trials}

Using a protocol modified after Sewell and Young (1999), the egg capsules were exposed to a range of temperatures (from 13 to $34.5^{\circ} \mathrm{C}$, see Table 2), including some of the higher temperatures that could be experienced in the intertidal zone during emersion (Zippay 2009). While some of the temperatures were outside the range of ecological relevancy, it was important for this study to identify the physiological limits imposed by temperature on survival for developing veligers. The number of temperature treatments varied slightly from site to site due to the number of egg capsules available for collection. For the actual assay, five to eight egg capsules were placed in an unsealed $20 \mathrm{~mL}$ glass scintillation vial containing filtered seawater $(0.35 \mu \mathrm{m})$, in triplicate at each of the different temperatures (Table 2). To eliminate the confounding effect of desiccation stress as a variable, egg capsules were exposed to the temperature treatments while immersed in seawater. After the 1-h incubation, egg capsules $(n=5-8)$ were cut open, and larvae were examined under a dissecting microscope and were scored for survivorship. Larvae that appeared to have ciliary movement around their velum were considered alive and those with no movement were scored as dead. Each capsule contained approximately 5-22 larvae.

Methodologically, temperature exposures of 1-2 $\mathrm{h}$ in duration are commonly used to analyze the physiological performance of larvae (Boon-Niermeijer and Van de Scheur 1984; Sewell and Young 1999; Brown et al. 2004). Although it is likely that Nucella egg capsules might experience more prolonged exposures to thermal stress in the field, we took a conservative approach in this study and chose a $1 \mathrm{~h}$ period for the assessment of survivorship. It is important to note that only advanced veliger-stage larvae were used for this experiment (as described by Gallardo 1979). Namely, if the larvae did not have distinct velar lobes, appearance of shell, eyespots, formation of foot, and operculum, then the whole egg capsule was eliminated from the experiment. These thermal tolerance trials were designed to measure veliger mortality across different temperatures, and these data were used to calculate the $\mathrm{LT}_{50}$ for that particular site. $\mathrm{LT}_{50}$ refers to the temperature at which $50 \%$ of the total experimental population was killed by the heat treatment (Stillman and Somero 2000; Hamdoun et al. 2003).

\section{Recovery experiment}

To assess if the observed $\mathrm{LT}_{50}$ was a true indication of larval mortality as opposed to a temporary state of torpor (i.e., a temporary state of decreased physiological activity) induced by the acute heat stress, a second experiment was conducted on $N$. ostrina larvae from Strawberry Hill, OR. Thirty-five egg capsules were collected from the field and subjected to a lethal $\left(34.5^{\circ} \mathrm{C}\right)$ and an acute $\left(31.7^{\circ} \mathrm{C}\right)$ heat shock for $1 \mathrm{~h}$ and allowed to recover for up to $1 \mathrm{~h}$ at the ambient seawater temperature for this population $\left(11^{\circ} \mathrm{C}\right)$. $N$. ostrina veligers were exposed to 31.7 and $34.5^{\circ} \mathrm{C}$ because these temperatures represent the $\mathrm{LT}_{50}$ and lethal temperature, respectively, for the Strawberry Hill, OR site.

Using the same thermal tolerance protocol as above, egg capsules $(n=35)$ were exposed to a $1 \mathrm{~h}$ heat shock, in triplicate, at the two temperatures $\left(\mathrm{LT}_{50}=31.7^{\circ} \mathrm{C}\right.$ and lethal $=34.5^{\circ} \mathrm{C}$ ). Immediately following the exposure, seven egg capsules were dissected and larvae survival rates
Table 2 Temperature incubation regimes for Nucella ostrina egg capsules for a particular site

\begin{tabular}{llll}
\hline Latitude & Sites & 1-h incubation temperatures $\left({ }^{\circ} \mathrm{C}\right)$ & $\mathrm{LT}_{50}\left({ }^{\circ} \mathrm{C}\right)$ \\
\hline \multirow{2}{*}{ North } & CP & $13,15,17.5,19.5,21.5,23.5,25.5,27.5,29.5,31.5,33.5$ & 30.1 \\
& BB & $13,19.5,25.5,29.5,31.5,34.5$ & 32.3 \\
& SH & $13,19.5,21.5,25.5,29.5,31.5,34.5$ & 31.7 \\
& CB & $13,17.5,19.5,21.5,25.5,29.5,31.5,33.5,34.5$ & 31.8 \\
& HUM & $13,19.5,21.5,23.5,25.5,29.5,31.5,33.5$ & 32.1 \\
\multirow{2}{*}{ South } & BML & $13,19.5,21.5,25.5,29.5,31.5,34.5$ & 33.6 \\
\hline
\end{tabular}


were determined. The remaining 28 egg capsules for each temperature were placed in the seawater table to recover. Every $15 \mathrm{~min}$ up to $1 \mathrm{~h}$, seven egg capsules were removed from the recovery seawater table and survival rates were determined. To obtain a baseline measurement of larval condition in the egg capsules with no heat stress (“control"), survival rates of larvae from $21 \mathrm{~N}$. ostrina egg capsules were quantified prior to any high temperature exposures.

\section{Statistical analyses}

For the thermal tolerance assays, analyses were performed using JMP 7.0 statistical software (SAS Institute Inc.). The $\mathrm{LT}_{50}$ of Nucella for each site was calculated using a $95 \%$ confidence interval where upper and lower limits of the $50 \%$ mortality were given. Analyses for the recovery experiment were performed using SigmaStat 3.0 statistical software. The average mortality was calculated for each recovery time point for veligers that were heat shocked at the $\mathrm{LT}_{50}$ temperature of $31.7^{\circ} \mathrm{C}$ and those that were heat shocked at $34.5^{\circ} \mathrm{C}$. All values were Box-Cox transformed to meet the assumptions of normality. The mean mortality values for each heat shock temperature were compared using one-way analyses of variance.

\section{Results}

Survivorship of Nucella ostrina veligers

Veliger larvae from all sites survived temperatures from 13 to $27.5^{\circ} \mathrm{C}$ (Fig. 1). As temperatures further increased, survivorship rapidly decreased within a narrow window of temperatures. Overall, regardless of the biogeographic collection site of the Nucella ostrina veligers tested in the thermal tolerance trials, the temperature at which death was first observed was separated by only $\sim 3-5^{\circ} \mathrm{C}$ from the temperature that caused nearly $100 \%$ mortality. For example, veligers from Cattle Point first experienced mortality at $29.5^{\circ} \mathrm{C}$ with $47.5 \%$ dead; this population experienced $100 \%$ mortality at $33.5^{\circ} \mathrm{C}$, a range of only $4^{\circ} \mathrm{C}$ (Fig. 1). A similar pattern was seen for other sites, such as Strawberry Hill and Humboldt, where only a few degrees $\left(5\right.$ and $3{ }^{\circ} \mathrm{C}$, respectively) separate the initial onset of mortality and $100 \%$ mortality (Fig. 1).

These mortality data were used to calculate the $\mathrm{LT}_{50}$ values for each collection site. In order to confirm that our calculated $\mathrm{LT}_{50}$ was a true lethal point for the veligers, we performed recovery experiments where veligers were assessed for mortality at two different temperatures and allowed to recover for $1 \mathrm{~h}$. Results showed no veligers survived the heat stress at the highest temperature of $34.5^{\circ} \mathrm{C}$ (Fig. 2), whereas veligers exposed to the lower tempera-

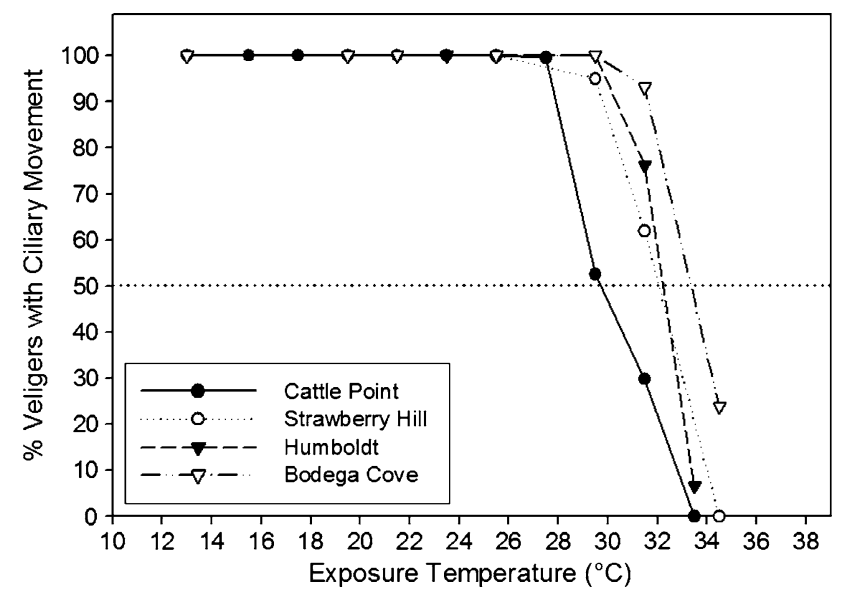

Fig. 1 The thermal tolerance profile for Nucella ostrina veligers from four out of the seven sites during May-July 2006. The $x$-axis corresponds to the exposure temperatures of egg capsules after 1-h incubation. The $y$-axis is an index of survivorship based upon veligers with ciliary movement around the velum after exposure. Each line represents the number alive compared to the overall total number of larvae used ( $n=5-8$ egg capsules, $n=5-22$ embryos per egg capsule)

ture, $31.7^{\circ} \mathrm{C}$ (the $\mathrm{LT}_{50}$ for Strawberry Hill), regained some ciliary movement over time. Using a one-way analysis of variance, the differences in the mean values among the recovery time points for the $\mathrm{LT}_{50}$ temperature $\left(31.7^{\circ} \mathrm{C}\right)$ were not significantly different $(F=1.998, \mathrm{df}=4, n=100$, $P=0.1008$ ), indicating that our protocol during the thermal trials was accurate and decisions to score larvae as dead were not biased by reversible inactivity of the larvae.

Relationship of thermal tolerance to site of collection

In the thermal tolerance trials, there was a relationship between larval thermal tolerance and the latitude at which the Nucella ostrina egg capsules were collected. Specifically, the northern populations of veligers were more sensitive to higher temperatures when compared to the veligers collected in the southern part of the range (Fig. 3). $N$. ostrina veligers collected from the most northerly site of Cattle Point had an $\mathrm{LT}_{50}$ of $30.1,3.8^{\circ} \mathrm{C}$ lower than the $\mathrm{LT}_{50}$ for $N$. ostrina veligers from the most southern site of Rancho Marino $\left(\mathrm{LT}_{50}=33.9^{\circ} \mathrm{C}\right.$, Fig. 3 and Table 2). When considered as a group, the veliger $\mathrm{LT}_{50}$ 's showed a pattern of least to most tolerance of high temperatures in the following order: $\mathrm{CP}<\mathrm{BB}>\mathrm{SH} \approx \mathrm{CB}<\mathrm{HUM}<\mathrm{BML} \approx \mathrm{RM}$ (Table 2). This latitudinal trend was confirmed in a linear regression model (Fig. 3, $P=0.0011, R^{2}=0.8995$ ).

\section{Discussion and conclusions}

In this study, we assessed the thermal tolerance of veliger larvae of Nucella ostrina, an intertidal dogwhelk, across its 


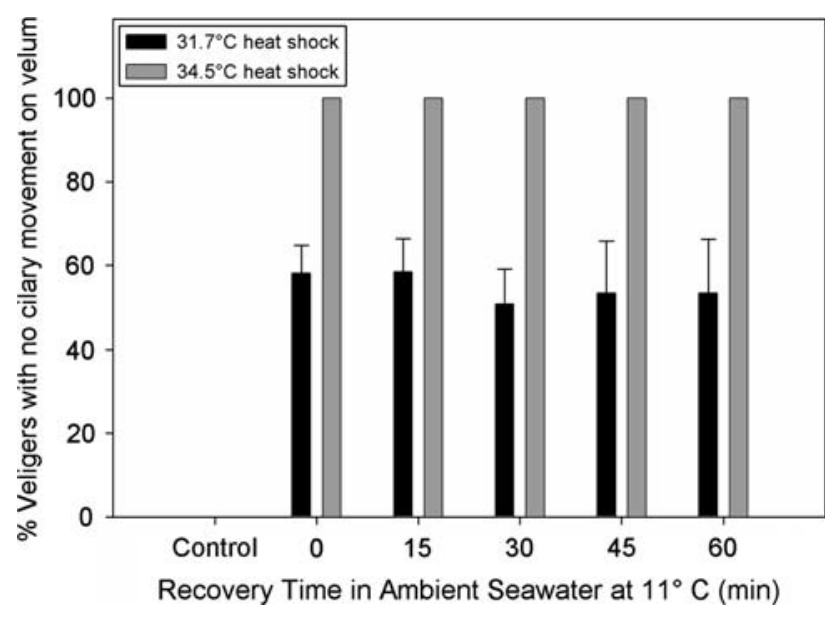

Fig. 2 Recovery experiment conducted with Nucella ostrina veligers from Strawberry Hill, OR. The $x$-axis corresponds to the time the veligers spent recovering at $11^{\circ} \mathrm{C}$ post-1-h heat shock. $Y$-axis is the percent of veligers with no ciliary movement on the velum after time spent recovering. Each bar represents the number dead compared to the overall total number of larvae used. The black bars correspond to veligers that were heat shocked at $31.7^{\circ} \mathrm{C}$, the $\mathrm{LT}_{50}$ for this particular site. Whereas, the light bars correspond to veligers that were exposed to their lethal temperature of $34.5^{\circ} \mathrm{C}$ (mean \pm standard deviation). No significant difference was detected across recovery time for the $\mathrm{LT}_{50}$ temperatures of $31.7^{\circ} \mathrm{C}(P=0.1008)$ nor for the lethal temperature of $34.5^{\circ} \mathrm{C}(P=1)$

biogeographic distribution and measured survivorship in laboratory trials across a range of ecologically relevant temperatures. There were two major findings in this study: (1) N. ostrina veligers displayed a sharp change in survivorship within just a few degrees at all sites, and (2) we found a significant relationship between veliger thermal tolerance and latitude.

\section{Larval thermal tolerance}

In the thermal trials, there was a rapid, linear increase in mortality occurring over a few degrees of temperature. Specifically, there was only $\sim 3-5^{\circ} \mathrm{C}$ difference between the temperature at which we first began to see mortality and the temperature where nearly $100 \%$ mortality was achieved across all the sites. Given the large-scale distribution of Nucella ostrina, a broader range of $\mathrm{LT}_{50}$ temperatures might be predicted. However, our data revealed a narrow window of thermal tolerance. For example, we observed a very small gap between survival and mortality, where the $\mathrm{LT}_{50}$ temperature for $N$. ostrina veligers collected from Strawberry Hill was $31.7^{\circ} \mathrm{C}$ when compared to the recorded lethal temperature of $34.5^{\circ} \mathrm{C}$. These slight differences in thermal tolerance indicate that there is an abrupt threshold for mortality that could have profound affects on survival where "ecological surprises" of sudden increases in temperature could precipitate mass mortality events (Harley et al. 2006)
While our study is the first to assess thermal tolerance, our observation of the narrow window between tolerance and mortality is consistent with other abiotic stressor studies of Nucella that also found broad range of tolerance followed by a sudden decline in survivorship of encapsulated veligers. Although the nature of the egg capsule can mitigate some of the abiotic stresses inherent to life in the intertidal (desiccation stress, osmotic shock, and UV radiation) (Pechenik 1982, 1983; Hawkins and Hutchinson 1988; Rawlings 1990; Russell and Phillips 2009a, b), there are thresholds where the protective capacity of the capsule fails. For example, in a study on desiccation stress, late stage veligers (in the formally $N$. emarginata, now referred to as $N$. ostrina, Marko 1998) could withstand up to $80 \%$ water loss from the capsule chamber before suffering substantial mortality (Rawlings 1995). In other studies, it has been shown that capsule wall thickness provides some protection against UV radiation. In a comparative study, the thicker-walled capsules of $N$. emarginata (now referred to as $N$. ostrina) were more resistant to UV stress and protected from UV-A radiation when compared to the thinnerwalled lower intertidal species, N. lamellosa (Rawlings 1996, Pechenik 1999).

Our finding of an acute increase in N. ostrina mortality at elevated temperatures is not isolated within larval biology; similar observations of sudden shifts in survivorship in response to thermal stress have been made in early life history stages of other marine invertebrates. Boon-Niermeijer and Van De Scheur (1984) found that a $1{ }^{\circ} \mathrm{C}$ increase $\left(39.5-40.5^{\circ} \mathrm{C}\right)$ in heat exposure for 3-day-old Lymnaea stagnalis, a gastropod mollusk, shifted mortality from 40 to $100 \%$. Similarly, in a non-marine invertebrate, larvae of two species of Drosophila, D. melanogaster and D. simulans, had percent survivorship that shifted from $100 \%$ to near zero when exposure temperatures were increased from 37 to $39.5^{\circ} \mathrm{C}$ (Krebs 1999). Responses of developing embryos to temperature, and the particular temperatures encountered during the normal breeding season, have been most extensively investigated in echinoderms (Andronikov 1975; Strathmann 1987; Fujisawa and Shigei 1990). Purple sea urchin (Strongylocentrotus purpuratus) embryos displayed abrupt changes in survival over just a $2^{\circ} \mathrm{C}$ span for both gastrulae and 4-arm larvae (L. M. Hammond, unpublished results). In an early study on five tropical species of sea urchins, Rupp (1973) found that the upper thermal limits of cleavage were near $34^{\circ} \mathrm{C}$, whereas egg fertilization was more thermally resistant and not affected until $36^{\circ} \mathrm{C}$, suggesting that larval development would cease if larvae were trapped in flat reef pools or lagoons where temperatures exceed $36^{\circ} \mathrm{C}$. Similarly, Sewell and Young (1999) reported that the ability for blastulae and later staged tropical sea urchin larvae (Echinometra lucunter) to survive short periods $(2 \mathrm{~h})$ of 
Fig. 3 Latitudinal comparison of veliger thermal tolerance for Nucella ostrina, distribution indicated by solid black line, during May-July 2006. Black dots, on the graph, represent the calculated $\mathrm{LT}_{50}$ for each site with error bars representing $\pm 95 \%$ confidence intervals. $Y$-axis represents latitude and correlates with the collection sites depicted by black dots on the map. The $x$-axis is the temperature at which $50 \%$ of the veligers died after a 1 -h exposure $\left(P=0.0011, R^{2}=0.8995\right)$

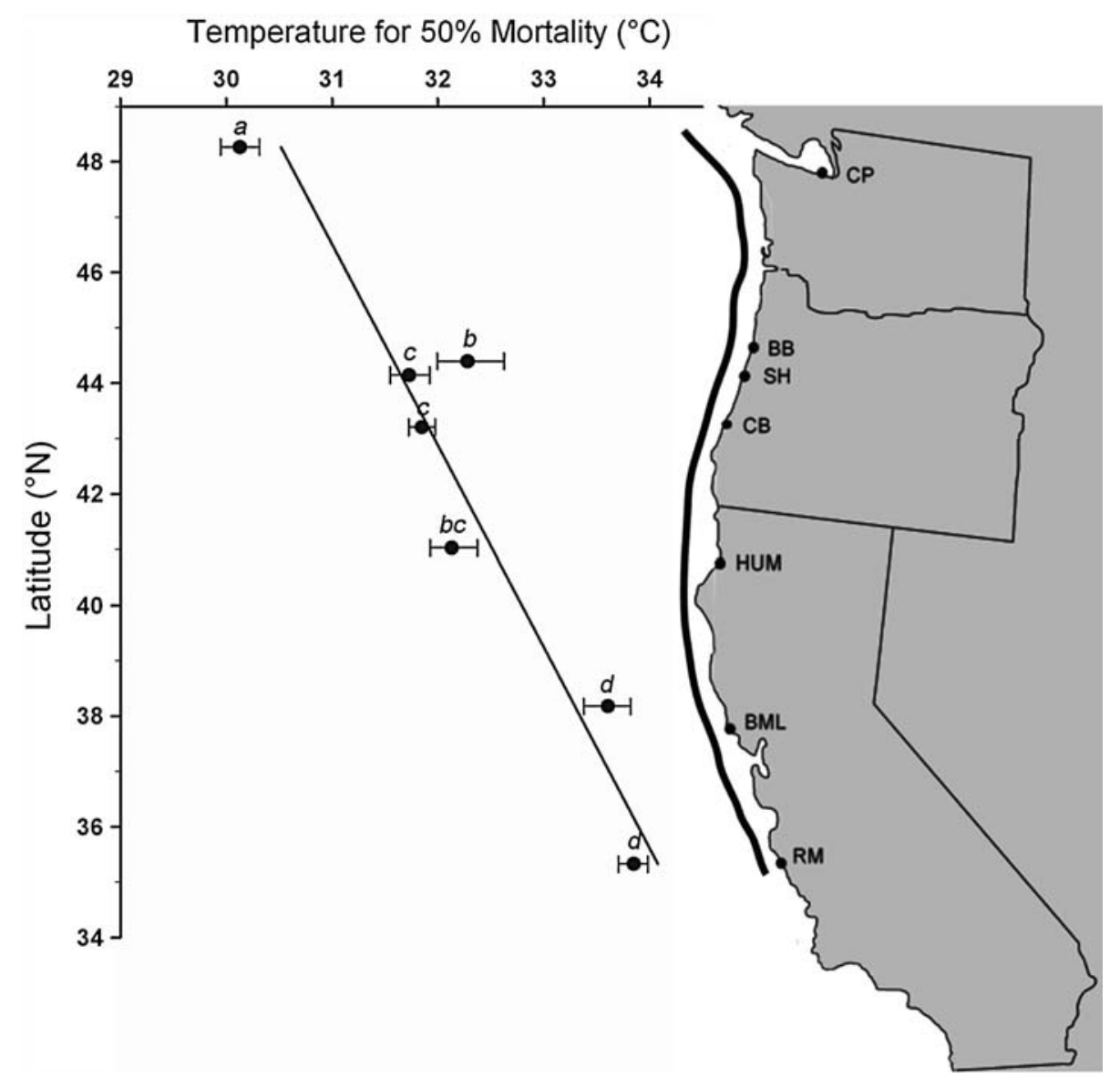

elevated temperatures $\left(4-5^{\circ} \mathrm{C}\right.$ higher than the $34^{\circ} \mathrm{C}$ upper limit for normal development) might be important if the larvae are carried to shallow waters of the Caribbean reef flats where seawater temperatures can reach $40^{\circ} \mathrm{C}$. In another experiment, significant increases in mortality were observed in the larvae of a brooding tropical coral, Porites astreoides, when exposed to slight increases in temperature from 28 to $33^{\circ} \mathrm{C}$ (Edmunds et al. 2001). Finally, in a polar species, successful larval development was achieved in a $3^{\circ} \mathrm{C}$ window, from +6 to $+9^{\circ} \mathrm{C}$, for the sub-Antarctic crab, Paralomis granulosa (Anger et al. 2003).

While all the above examples help to explain the importance of understanding how temperature limitations influence early developmental stages of larvae, they also highlight the scarcity of data on the temperature impacts on non-planktonic larvae. From an ecological perspective, this study contributes to our understanding of how conditions in the intertidal might influence larval survival. In a more global context, these data also suggest that increased air and seawater temperatures due to global climate change may also increase mortality during extreme heat events (Hoegh-Guldberg 1999; Pandolfi et al. 2003; Denny et al. 2009).
Relationship of thermal tolerance and latitude

Our data suggest a strong latitudinal relationship between calculated $\mathrm{LT}_{50}$ temperature and site. Larvae from more southerly distributed populations were more thermally tolerant than northern populations. For $N$. ostrina veligers collected from Cattle Point, the $\mathrm{LT}_{50}$ was $30.1^{\circ} \mathrm{C}$ when compared to an $\mathrm{LT}_{50}$ of $33.9^{\circ} \mathrm{C}$ of veligers collected at the more southerly location of Rancho Marino Reserve (Table 2). Few other studies have addressed the relationship of biogeography and the physiological tolerances of larval forms. One such study found a modest correlation between thermal tolerance and biogeography for echinopluteus larvae of Strongylocentrotus purpuratus. Larvae spawned from Oregon adults $\left(\mathrm{LT}_{50}=29.7^{\circ} \mathrm{C}\right)$ were more thermally sensitive than those larvae collected from Baja California, Mexico urchins $\left(\mathrm{LT}_{50}=31^{\circ} \mathrm{C}\right.$ ) (L. M. Hammond, unpublished results).

In contrast to the limited data on larval forms, the correlation of thermal tolerance with latitude and environment has been documented in adult forms of many marine invertebrates (see review Vernberg 1962; Stillman and Somero 2000; Somero 2005; Sorte and Hofmann 2005; Jansen et al. 2007) and in other ectotherms (e.g., Drosophila melanogaster-Hoffmann et al. 2002, mosquitoes_Zani et al. 2005, 
Fundulus heteroclitus_-Fangue et al. 2006). Similar to our results, Urban (1994) found a correlation between $\mathrm{LT}_{50}$ temperature and geographical distribution for adults of 10 bivalve species from Peru and Chile over $22^{\circ}$ of latitude.

In summary, the current study showed that Nucella ostrina veligers displayed different thermal tolerances as a function of the latitude at which they were collected. The data presented here are a conservative measurement of the upper limits of physiological thresholds of encapsulated larvae. Overall, these data suggest that larval stages of this intertidal invertebrate may not be a hyper-vulnerable life stage (see also Hamdoun and Epel 2007). This observation is further supported by other studies, for example, on an intertidal bivalve which found that early life stages and adults had similar thermal tolerances. The oyster, Ostreola conchaphila, brood their young and adults and veliger larvae survive the same lethal temperatures of $38.5-39^{\circ} \mathrm{C}$ (Brown et al. 2004). However, changing thermal patterns due to climate change may significantly increase mortality during larval development and result in population fragmentation based on the latitudinal timing of low tides and tendency for local adaptation (Sanford et al. 2006).

Acknowledgments We would like to thank our field assistants (Tim Crombie, Jessica Dutton, Dr. Sarah Henkel, Elizabeth Hoaglund, and Dr. Chris Osovitz) for their help with intertidal collections. We are grateful to Drs. Mary Sewell and Kathy Foltz for helpful comments during the preparation of this manuscript. This research was conducted at the University of California Natural Reserve System Bodega Marine Laboratory/Reserve, Coal Oil Point Natural Reserve, Kenneth S. Norris Rancho Marino Reserve, and Scripps Reserve and supported by a Mildred E. Mathias Graduate Student Research Grant from the University of California Natural Reserve System (to MLZ). Partial support also came from an Alan J. Kohn Graduate Student Fellowship from Friday Harbor Laboratories at the University of Washington (to MLZ). Preparation of this manuscript was partially supported by the University of California Marine Council, Coastal Environmental Quality Initiative Graduate Student Fellowship to MLZ and by the US National Science Foundation grant OCE-0425107 to GEH. This is contribution number 346 from PISCO, the Partnership for Interdisciplinary Studies of Coastal Oceans funded primarily by the Gordon and Betty Moore Foundation and David and Lucile Packard Foundation. The described experiments and specimens collections comply with the current laws of the United States of America and the regulations of the California Department of Fish and Game.

Open Access This article is distributed under the terms of the Creative Commons Attribution Noncommercial License which permits any noncommercial use, distribution, and reproduction in any medium, provided the original author(s) and source are credited.

\section{References}

Andronikov VB (1975) Heat resistance of gametes of marine invertebrates in relation to temperature conditions under which the species exist. Mar Biol 30:1-11

Anger K, Thatje S, Lovrich GA, Calcagno JA (2003) Larval and early juvenile development of Paralomis granulosa reared at different temperatures: tolerance of cold and food limitation in a lithodid crab from high latitudes. Mar Ecol Prog Ser 253:243-251

Boon-Niermeijer E, Van De Scheur H (1984) Thermosensitivity during embryonic development of Lymnaea stagnalis (Mollusca). J. Therm. Biol. 9:265-269

Brown HM, Briden A, Stokell T, Griffin FJ, Cherr GN (2004) Thermotolerance and Hsp70 profiles in adult and embryonic California native oysters, Ostreola conchaphila (Carpenter, 1857) J. Shellfish Res 23:135-141

Collins TM, Frazer K, Palmer AR, Vermeji GJ, Brown WM (1996) Evolutionary History of Northern hemisphere Nucella (Gastropoda, Muricidae): Molecular, Morphological, Ecological, and Paleontological Evidence. Evolution 50:2287-2304

Connell JH (1985) The consequences of variation in initial settlement vs post settlement mortality in rocky intertidal communities J Exp Mar Biol Ecol 93:11-45

Costello DP, Henley C (1971) Methods for obtaining and handling marine eggs and embryos, 2ed. Woods Hole. Massachusetts, Marine Biology Laboratory, p 247

Denny MW, Hunt LJH, Miller LP, Harley CDG (2009) On the prediction of extreme ecological events. Ecol Monographs 79:397-421

Edmunds PJ, Gates RD, Gleason DF (2001) The biology of larvae from the reef coral Porites astreoides, and their response to temperature disturbances. Mar Biol 139:981-989

Etter RJ (1996) The effect of wave action, prey type, and foraging time on growth of the predatory snail Nucella lapillus (L). J Exp Mar Biol and Ecol 196:341-356

Fangue NA, Hofmeister M, Schulte PM (2006) Intraspecific variation in thermal tolerance and heat shock protein gene expression in common killifish, Fundulus heteroclitus. J Exp Biol 209:28592872

Feare CJ (1970) Aspects of ecology of an exposed shore population of dogwhelks Nucella lapillus (L). Oecologia 5:1-18

Fernández M, Calderón R, Cancino JM, Jeno K (2007) The effect of temperature on the development of encapsulated embryos of Concholepas concholepas along a latitudinal cline. Mar Ecol Prog Ser 348:229-237

Fujisawa H, Shigei M (1990) Correlation of embryonic temperature sensitivity of sea urchins with spawning season. J Exp Mar Biol Ecol 136:123-139

Gallardo CS (1979) Developmental Pattern And Adaptations For Reproduction In Nucella crassilabrum And Other Muricacean Gastropods. Biol Bull 157:453-463

Gosselin LA, Chia F-S (1995a) Distribution and dispersal of early juveniles snails: effectiveness of intertidal microhabitats as refuges and food sources. Mar Ecol Prog Ser 128:213-223

Gosselin LA, Chia F-S (1995b) Characterizing temperate rocky shores from the perspective of an early juvenile snail: the main threats to survival of newly hatched Nucella emarginata. Mar Biol 122:625-635

Gosselin LA, Qian PY (1997) Juvenile mortality in benthic marine invertebrates. Mar Ecol Prog Ser 146:265-282

Gosselin LA, Rehak R (2007) Initial juvenile size and environmental severity: influence of predation and wave exposure on hatching size in Nucella ostrina. Mar Ecol Prog Ser 339:143-155

Hamdoun A, Epel D (2007) Embryo stability and vulnerability in an always changing world. Proc Natl Acad Sci USA 104:17451750

Hamdoun AM, Cheney DP, Cherr GN (2003) Phenotypic plasticity of HSP70 and HSP70 gene expression in the Pacific oyster (Crassostrea gigas): Implications for thermal limits and induction of thermal tolerance. Biol Bull 205:160-169

Harley CDG, Randall Hughes A, Hultgren KM, Miner BG, Sorte CJB, Thornber CS, Rodriguez LF, Tomanek L, Williams SL (2006) The impacts of climate change in coastal marine systems. Ecol Lett 9:228-241 
Hawkins LE, Hutchinson S (1988) Egg capsule structure and hatching mechanism of Ocenebra erinacea (L) (Prosobranchia, Muricidae). J Exp Mar Biol Ecol 119:269-283

Hoegh-Guldberg O (1999) Climate change, coral bleaching and the future of the world's coral reefs. Mar Freshw Res 50:839-866

Hoffmann AA, Anderson A, Hallas R (2002) Opposing clines for high and low temperature resistance in Drosophila melanogaster. Ecol Lett 5:614-618

Jackson GA, Strathmann RR (1981) Larval mortality from offshore mixing as a link between pre-competent and competent periods of development. Am Nat 118:16-26

Jansen JM, Pronker AE, Kube S, Sokolowski A, Sola JC, Marquiegui MA, Schiedek D, Bonga SW, Wolowicz M, Hummel H (2007) Geographic and seasonal patterns and limits on the adaptive response to temperature of European Mytilus spp. and Macoma balthica populations. Oecologia 154:23-34

Krebs RA (1999) A comparison of Hsp70 expression and thermotolerance in adults and larvae of three Drosophila species. Cell Stress Chaperones 4:243-249

LeBoeuf R (1971) Thais emarginata (Deshayes): Description of the Veliger and Egg Capsules. Veliger 14:205-211

Lu J, Lin Q, Sun Y, Sheng J, Chen Q (2004) Effects of temperature on the early development of Haliotis diversicolor Reeve. J. Shellfish Res 4:963-966

Marko PB (1998) Historical allopatry and the biogeography of speciation in the prosobranch snail genus Nucella. Evol 52:757-774

Moran AL, Emlet RB (2001) Offspring size and performance in variable environments: field studies on a marine snail. Ecol 82:1597-1612

Morris RH, Abbott DP, Haderlie EC (1980) Intertidal invertebrates of California. Stanford University Press, Stanford, CA

O'Connor MI, Bruno JF, Gaines SD, Halpern BS, Lester SE, Kinlan BP, Weiss JM (2007) Temperature control of larval dispersal and the implications for marine ecology, evolution, and conservation. Proc Natl Acad Sci USA 104:1266-1271

Palmer AR (1990) Reproductive, morphological, and genetic evidence for two cryptic species of Northeastern Pacific Nucella. Veliger 33:325-338

Pandolfi JM, Bradbury RH, Sala E, Hughes TP, Bjorndal KA, Cooke RG, McArdle D, McClenachan L, Newman MJH, Paredes G, Warner RR, Jackson JBC (2003) Global trajectories of the longterm decline of coral reef ecosystems. Science 301:955-958

Pechenik JA (1982) Ability Of Some Gastropod Egg Capsules To Protect Against Low-Salinity Stress. J Exp Mar Biol Ecol 63:195-208

Pechenik JA (1983) Egg capsules of Nucella lapillus (1.) Protect against low-salinity stress. J Exp Mar Biol Ecol 71:165-179

Pechenik JA (1999) On the advantages and disadvantages of larval stages in benthic marine invertebrates life cycles. Mar Ecol Prog Ser 177:269-297

Pedersen G, Tande KS (1992) Physiological plasticity to temperature in Calanus finmarchicus. Reality or artifact? J Exp Mar Biol Ecol 155:183-197

Przeslawski R (2005) Combined effects of solar radiation and desiccation on the mortality and development of encapsulated embryos of rocky shore gastropods. Mar Ecol Prog Ser 298:169-177

Qian PY, Chia FS (1994) In Situ measurement of recruitment, mortality, growth, and fecundity of Capitella sp (Annelida, Polychaeta). Mar Ecol Prog Ser 111:53-62

Rawlings TA (1990) Associations between egg capsule morphology and predation among populations of the marine gastropod, Nucella emarginata. Biol Bull 179:312-325

Rawlings TA (1995) Direct observation of encapsulated development in muricid gastropods. Veliger 38:54-60

Rawlings TA (1996) Shields against ultraviolet radiation: an additional protective role for the egg capsules of benthic marine gastropods. Mar Ecol Prog Ser 136:81-95
Rawlings TA (1999) Adaptations to physical stresses in the intertidal zone: The egg capsules of neogastropod molluscs. Am Zool 39(2):230-243

Roegner GC, Mann R (1995) Early recruitment and growth of the american oyster Crassostrea virginica (Bivalvia, Ostreidae) with respect to tidal zonation and season. Mar Ecol Prog Ser 117:91-101

Rupp JH (1973) Effects of temperature on Fertilization and early cleavage of some tropical echinoderms, with emphasis on Echinometra mathaei. Mar Biol 23:183-189

Russell J, Phillips N (2009a) Species-Specific Vulnerability of Benthic Marine Embryos of Congeneric Snails (Haminoea spp.) to Ultraviolet Radiation and Other Intertidal Stressors. Biol Bull 217:65-72

Russell J, Phillips NE (2009b) Synergistic effects of ultraviolet radiation and conditions at low tide on egg masses of limpets (Benhamina obliquata and Siphonaria australis) in New Zealand. Mar Biol 156:579-587

Sanford E, Holzman SB, Haney RA, Rand DM, Bertness MD (2006) Larval tolerance, gene flow, and the northern geographic range limit of fiddler crab. Ecology 87:2882-2894

Seavy DK (1977) Seasonal gametogenesis and egg laying in the prosobranch gastropods Nucella lamnellosa, Nucella emarginata, Searlesia dira, and Amphissa columbiana on the Oregon coast. Dissertation. Oregon State University, Corvallis, Oregon, USA

Sewell MA, Young CM (1999) Temperature limits to fertilization and early development in the tropical sea urchin Echinometra lucunter. J Exp Mar Biol Ecol 236:291-305

Somero GN (2005) Linking biogeography to physiology: Evolutionary and acclimatory adjustments of thermal limits. Front Zoo 2:1 doi:10.1186/1742-9994-2-1

Sorte CJB, Hofmann GE (2005) Thermotolerance and heat-shock protein expression in Northeastern Pacific Nucella species with different biogeographical ranges. Mar Biol 146:985-993

Spight TM (1976) Ecology of hatching size for Marine Snails. Oecologia (Berl.) 24:283-294

Spight TM, Emlen J (1976) Clutch sizes of two marine snails with a changing food supply. Ecol 57:1162-1178

Stillman JH, Somero GN (2000) A comparative analysis of the upper thermal tolerance limits of eastern Pacific porcelain crabs, genus Petrolisthes: Influences of latitude, vertical zonation, acclimation, and phylogeny. Physiol Biochem Zool 73:200-208

Strathmann MF (1987) Reproduction and Development of Marine Invertebrates of The Northern Pacific Coast: Data And Methods For The Study Of Eggs, Embryos, And Larvae. University of Washington Press, Seattle, Washington, USA; London, England, Uk. Illus, pp Xii $+670 p$

Sultan SE (2007) Development in context: the timely emergence of eco-devo. Trends Ecol Evol 22:575-582

Thorson G (1950) Reproductive and Larval Ecology of Marine Bottom Invertebrates. Biol Rev 25:1-45

Urban HJ (1994) Upper Temperature Tolerance Of 10 Bivalve Species Off Peru And Chile Related To El-Nino. Mar Ecol Prog Series 107:139-145

Vermeij GJ, Palmer AR, Lindberg DR (1990) Range limits and dispersal of molluscs in the Aleutian islands, Alaska. The Veliger 33:346-354

Vernberg FJ (1962) Comparative physiology: Latitudinal effects on physiological properties of animal populations. Annu Rev Physiol 24:517-546

Wilson JG (1973) Environment and Birth Defects. Academic, New York

Zani PA, Swanson SET, Corbin D, Cohnstaedt LW, Agotsch MD, Bradshaw WE, Holzapfel CM (2005) Geographic variation in tolerance of transient thermal stress in the mosquito Wyeomyia smithiii. Ecol 86:1206-1211

Zippay ML (2009) The Physiological Response of Larval Marine Snails to Environmental Stressors. Dissertation, University of California, Santa Barbara, CA, USA 